\title{
COMPETITIVENESS OF DESTINATIONS WITHIN THE RURAL TOURISM CLUSTER: ZLATAR, ZLATIBOR
}

\author{
Sanja Pavlovićn ${ }^{11}$ Gordana Čavlin ${ }^{22}$
}

\begin{abstract}
Summary
Cluster analysis is gaining increasing importance in the contemporary development of tourism. These are mostly areas that have similar tourist values. This paper presents the competitiveness of tourist destinations in the cluster of rural tourism Zlatar, Zlatibor, as defined in the Master Plan for Sustainable Development of Rural Tourism in Serbia. Having used AHP (Analytic Hierarchy Process) criteria pairs have been first compared, and then the alternatives (villages of Zlatar and Zlatibor). The seven criteria used in this paper are the following: factors and attractors, accessibility and infrastructure, accommodation facilities, unemployment, experience in rural tourism, proximity of the marketplace, and seasonality. The AHP method has been used to determine relations between the influence factors and the dominance of one factor in relation to another.It has been noted a relatively weak dominance of the villages of Zlatibor, by all criteria, except when it comes to unemployment, which is dominated by the villages of Zlatar.
\end{abstract}

Key words: rural tourism, competitiveness, cluster, Zlatar, Zlatibor

JEL: C38, L83

\section{Introduction}

A universal program of development of rural areas does not exist because it depends on the characteristics of a particular area. Therefore, the condition for the development of a model of development in rural areas is the adequate regionalization, based on comparative advantages and analysis of indicators of development and quality of life (Todorović, Štetić, 2009).

The development of rural tourism should be focused on expansion, differentiation and unification, while the implications will be reflected in the growing competition, forming of partnership alliances, more effective marketing, and sustainable tourism policy. In practice,

1 Sanja Pavlović, Ph.D., Assistant professor, University of Belgrade, Faculty of Geography, Studentski trg 3/III, 11000 Belgrade, Serbia, Phone: +381 6425884 68, E-mail: spavlovic20@gmail.com

2 Gordana Čavlin, mr. sci. oecc., Provincial Secretariat for Health and Social Affairs - Novi Sad, Department Subotica, Serbia, Phone: +381 6288487 36, E-mail: goca.cavlin@gmail.com

EP 2014 (61) 3 (603-614) 
integrated management contributes to the achievement of sustainable rural development (Štetić et al., 2013).

The aim of bringing the attractiveness and competitiveness together is to facilitate investment in what tourists are most interested in, and it is of mutual interest to both tourists and residents. The competitiveness of a tourist destination is its ability to increase its attractiveness in accordance to the requirements of tourism demand, which will also be reflected on the increase in tourism spending. If development of a rural tourism destination is directed in this way, its long-term competitiveness could be achieved (Vuković et al., 2010).

Clusters are gaining increasing importance in both theoretical and practical contexts of the contemporary tourism development, taking into consideration the geographic concentration of related companies, suppliers, service providers, who simultaneously cooperate and compete with each other. In tourism, clusters are subareas or micro-destinations within a tourist region, which have similar tourist values (Todorović, Štetić, 2009).

Master Plan for Sustainable Development of Rural Tourism in Serbia (2011) has distinguished 12 clusters of rural tourism. These clusters are grouped into four groups of clusters of rural tourism, with respect to synergy and proximity of one or more clusters. In the group of rural tourism clusters in Central and Western Serbia the following clusters are distinguished: Golija, Zlatar, Zlatibor, Kopaonik, and Central Serbia.

The second group of clusters consists of the South Banat and Donje Podunavlje, the third group of clusters (Eastern Serbia) includes the following clusters: Sokobanja, Eastern Serbia and South-Eastern Serbia. The fourth group of clusters (Vojvodina) comprises the following clusters: Fruška gora, Gornje Podunavlje and Northern Vojvodina.

\section{Research Methodology}

One of the methods for comparing and ranking alternatives (in this paper, destinations within the rural tourism cluster Zlatibor, Zlatar) is a method of AHP (Analytic Hierarchy Process). It is based on a comparison of alternatives in pairs. Analytic Hierarchy Process was developed by Thomas L. Saaty (1990), when he separated the components: goal, criteria and alternatives and linked them into a model, in which the goal is at the highest level, while criteria (and sub-criteria, if there are any) are at a lower, and the alternatives at the lowest level. It is necessary to determine the relative importance of the two criteria in the AHP method, i.e. compare the importance of all pairs of criteria, assigning them the value of the claims presented in Table 1 . The selection of claims signifies appropriate quantification of the weight of criteria. The AHP method is flexible because it allows the relations between influencing factors to be distinguished on the basis of examples of various criteria and alternatives, and also recognizes their explicit or relative influence and importance in real-world conditions and determines the dominance of one factor over another. 
The aim of this paper is to highlight the importance of the method of multi-criteria analysis in relation to the assessment of the competitiveness of rural tourism destinations. With the aim of the paper being defined in this way, a hypothesis can be deduced: by using the criteria defined by the World Tourism Organization and the multi-criteria analysis it is possible to identify a hierarchy of villages of Zlatibor and Zlatar mountains within the context of the development of rural tourism.

Table 1.Relative scores of pairs of attributes at one hierarchical level (Saaty's scale)

\begin{tabular}{|l|l|l|}
\hline Importance & \multicolumn{1}{|c|}{ Definition } & \multicolumn{1}{c|}{ Explanation } \\
\hline 1 & Equal importance & $\begin{array}{l}\text { Two elements are of identical importance in } \\
\text { respect to the objective }\end{array}$ \\
\hline 3 & Weak dominance & $\begin{array}{l}\text { Experience or judgment slightly favorites one } \\
\text { element over the other }\end{array}$ \\
\hline 5 & Strong dominance & $\begin{array}{l}\text { Experience or judgment significantly favorites one } \\
\text { element over the other }\end{array}$ \\
\hline 7 & Demonstrated dominance & Dominance of one element confirmed in practice \\
\hline 9 & Absolute dominance & Dominance of the highest degree \\
\hline $2,4,6,8$ & Inter-values & Necessary compromise or further division \\
\hline
\end{tabular}

Source: Saaty, T. L., 1990.

\section{Research Results and Discussion}

In order to determine the priorities for development in comparison with other clusters of rural tourism in the Master Plan for Sustainable Rural Tourism in Serbia (2011) the following criteria, which affect the quality management of rural areas, have been applied:

1. concentration of factors and attractors and the potential of a cluster to develop a diversified offer in rural tourism;

2. seasonality is observed by concluding whether the cluster provides a year-round tourist offer;

3. accessibility and infrastructure with regard to the access and movement possibilities within the cluster;

4. the proximity of the marketplace;

5. unemployment defined in relation to the percentage of the unemployed in the total active population, taking into account that a high proportion of the unemployed should be given priority in the development of rural tourism;

6. accommodation facilities;

7. experience in rural tourism of each cluster in the development and management of tourism.

The same criteria have been applied in the analysis of the competitiveness of villages on Zlatibor and Zlatar mountains, which are located in the cluster of rural tourism Zlatar, Zlatibor. Initially, the assessment of the priority of the attributes (criteria) has been done by comparing their pairs, with the $\mathrm{K} 1$ being factors and attractors, K2 seasonality, K3 
accessibility and infrastructure, K4 proximity of the marketplace, K5 unemployment, K6 accommodation facilities, and K7 experience in rural tourism.

Table 2. Assessment of priorities of attributes (criteria) - comparison in pairs

\begin{tabular}{|l|c|c|c|c|c|c|c|}
\hline & K1 & K2 & K3 & K4 & K5 & K6 & K7 \\
\hline K1 & 1,00000 & 7,00000 & 2,00000 & 6,00000 & 4,00000 & 3,00000 & 5,00000 \\
\hline K2 & 0,14286 & 1,00000 & 0,16667 & 0,50000 & 0,25000 & 0,20000 & 0,33333 \\
\hline K3 & 0,50000 & 6,00000 & 1,00000 & 5,00000 & 3,00000 & 2,00000 & 4,00000 \\
\hline K4 & 0,16667 & 2,00000 & 0,20000 & 1,00000 & 0,33333 & 0,25000 & 0,50000 \\
\hline K5 & 0,25000 & 4,00000 & 0,33333 & 3,00000 & 1,00000 & 0,50000 & 2,00000 \\
\hline K6 & 0,33333 & 5,00000 & 0,50000 & 4,00000 & 2,00000 & 1,00000 & 3,00000 \\
\hline K7 & 0,20000 & 3,00000 & 0,25000 & 2,00000 & 0,50000 & 0,33333 & 1,00000 \\
\hline$\sum$ & 2,59286 & 28,00000 & 4,45000 & 21,50000 & 11,08333 & 7,28333 & 15,83333 \\
\hline
\end{tabular}

Source: research results based on the criteria of the Master Plan for Sustainable Rural Tourism in Serbia (2011) and empirical experience.

When comparing, for each pair of criteria (starting from $\mathrm{K} 1$ and $\mathrm{K} 2$, for example) the value of a criterion's significance in relation to the other one should be entered. At position (K2, K1) in the matrix of the results of comparison, i.e. at the position of the section lines between $\mathrm{K} 2$ and $\mathrm{K} 1$ columns the value $1 / 7$ has been entered, which means that abstract factors (criterion $\mathrm{K} 1$ ) have exhibited dominance, confirmed in practice, in relation to the seasonality (criterion $\mathrm{K} 2$ ), which puts them in a reciprocal relation.

The values of the elements (criteria) by columns are summarized and the sum $(\Sigma)$ is calculated (Table 2.). Each number in Table 2 is divided by the value of the column sum in which it is located. For example, the first value in Table 2. (1) is divided by the sum of the column $\mathrm{K} 1$ (2.59286), then the value 0.14286 is divided by 2.59286 , and so on. Other values are calculated in the same way in Table 3. Then values of each row in Table 3 are summarized and the median value for each row is determined $(\Sigma=\mathrm{W} / 7)$. These median values are also found in Table 11 and are used to obtain the criterion function by multiplying the value for the given criterion with the obtained weight of the criterion.

Table 3. Median value of each row (assessment of priorities of attributes)

\begin{tabular}{|c|c|c|c|c|c|c|c|c|c|}
\hline & K1 & K2 & K3 & K4 & K5 & K6 & K7 & $\sum$ & $\mathbf{W}=\sum / 7$ \\
\hline K1 & 0,386 & 0,250 & 0,449 & 0,279 & 0,361 & 0,412 & 0,316 & 2,453 & 0,350 \\
\hline K2 & 0,055 & 0,036 & 0,037 & 0,023 & 0,023 & 0,027 & 0,021 & 0,223 & 0,032 \\
\hline $\mathbf{K 3}$ & 0,193 & 0,214 & 0,225 & 0,233 & 0,271 & 0,275 & 0,253 & 1,662 & 0,237 \\
\hline K4 & 0,064 & 0,071 & 0,045 & 0,047 & 0,030 & 0,034 & 0,032 & 0,323 & 0,046 \\
\hline K5 & 0,096 & 0,143 & 0,075 & 0,140 & 0,090 & 0,069 & 0,126 & 0,739 & 0,106 \\
\hline K6 & 0,129 & 0,179 & 0,112 & 0,186 & 0,180 & 0,137 & 0,189 & 1,113 & 0,159 \\
\hline K7 & 0,077 & 0,107 & 0,056 & 0,093 & 0,045 & 0,046 & 0,063 & 0,488 & 0,070 \\
\hline$\sum$ & 1,000 & 1,000 & 1,000 & 1,000 & 1,000 & 1,000 & 1,000 & 7,000 & 1,000 \\
\hline
\end{tabular}

Source: research results based on the criteria of the Master Plan for Sustainable Rural Tourism in Serbia (2011) and empirical experience. 
Figure 1. Map of Zlatibor and Zlatar

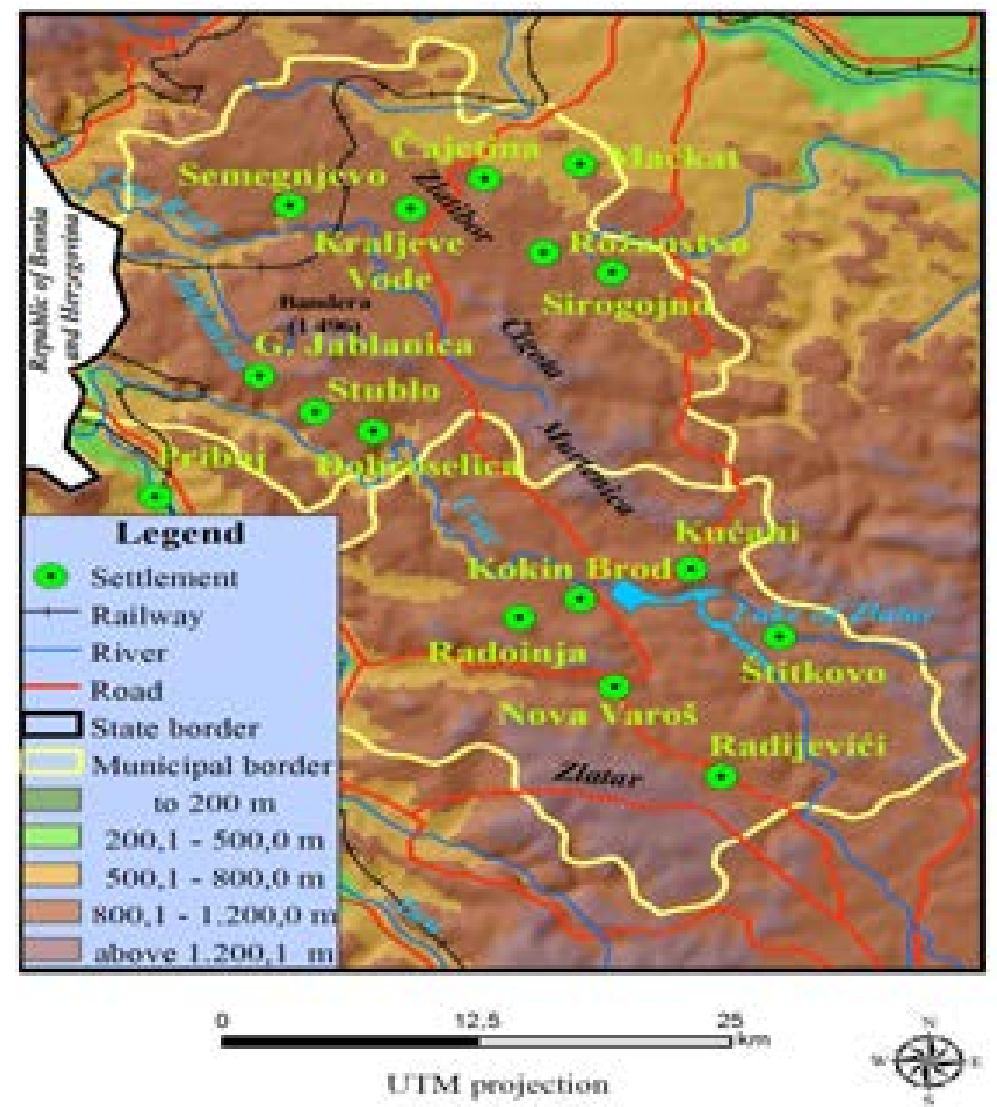

Note: The map was done for the purpose of this work and its author is Jovanović, R.

Alternatives analyzed in this paper are the following: A1 - villages on Zlatar Mountain and A2 - villages on Zlatibor Mountain. Zlatibor as the geographical term implies a rolling-hills plateau in South-Western Serbia, between the rivers Sušica, Uvac, Tara and Murtenica. The following villages are situated in this area: Negbina, Sjeništa, Bela Reka, Ljubiš, Gostilje, Dobroselica, Sirogojno, Rožanstvo, Semegnjevo, Tripkova, Šljivovica, Mačkat. Some of tourist motives in these settlements are: Stopića cave, the Crni Rzav river and its tributaries, waterfall in Gostilje where there is the birthplace of Dimitrije Tucović, a prominent hero of the labor movement, a wooden church in Dobroselica, the Museum of folk architecture in Sirogojno, a village that is known for its traditional handicrafts. Zlatar is a mountain in the South-Western Serbia, situated between the rivers Uvac and Lim. A special form of relief is the cave system of Ušac with its curiously unique properties. Tourist motives in this area are the following lakes: Zlatarsko, Radoinjsko and Sjeničko (Štetić, 2007).

Tourist offer of the region includes: the Uvac Special Nature Reserve with griffon vulture habitats, ethno village Štitkovo, eco-ethno village Vraneša, wooden churches in Kućani 
and Radijevići and Dubnica monastery. The project Improvement of Organic Agricultural Production in Mountainous Regions of Serbia, which is funded through the competitive grant scheme (CGS) as a part of the STAR project of the Ministry of Agriculture, Forestry and Water Management includes a manifestation called the Field Days and Organic Production of Buckwheat and Grain organized on Zlatar mountain by the Faculty of Agriculture, University of Belgrade. Also, villages on this mountain organize Zlatar Cheese Festival and Country Olympics (www.zlatar.org.rs/seoski.htm). In a Zlatibor village Tripkova an art colony and an art workshop for making glass as well as international seminars on Serbian folklore are organized in summer, while Pršutijada (festival of smoked ham) is organized in Mačkat and in Sirogojno there are art, music, and literary gatherings, exhibitions, lectures and summer schools (www.zlatibor.org.rs/k/rural tourism).

Factors determined by the methodology of the World Tourism Organization that are applied in the Master Plan for Sustainable Rural Tourism in Serbia (2011) are the following: natural, human and capital factors, while attractors are: natural (activities based on natural tourist motives), cultural (lifestyle, events, cultural tourism motives) and attractors in the form of centers of activity (shopping, festivals).

Table 4. Comparison of alternatives (destinations) in relation to $\mathrm{K} 1$ criterion - factors and attractors

\begin{tabular}{|c|c|c|}
\hline & $\mathbf{A 1}$ & $\mathbf{A 2}$ \\
\hline $\mathbf{A 1}$ & 1,00000 & 0,33333 \\
\hline $\mathbf{A 2}$ & 3,00000 & 1,00000 \\
\hline$\Sigma$ & 4,00000 & 1,33333 \\
\hline
\end{tabular}

Source: research results based on information from the websites of local tourism organizations - www.zlatibor.org.rs/k/seoski-turizam, www.zlatar.org.rs/seoski.htm

Villages on Zlatar and Zlatibor mountains are developing destinations. A developing rural tourist destination usually involves few developed attractors, poorly developed allied and support industries, many factors with the potential for development and the need for relatively large investments in order to convert factors into attractors. A developed rural tourism destination usually consists of a lot of developed attractors, developed allied and support industries, several factors that need to be developed and relatively little need for investment so that factors can be converted into attractors.

Table 5. Comparison of alternatives in relation to $\mathrm{K} 2$ criterion - seasonality

\begin{tabular}{|c|c|c|}
\hline & A1 & A2 \\
\hline $\mathbf{A 1}$ & 1,00000 & 0,25000 \\
\hline $\mathbf{A 2}$ & 4,00000 & 1,00000 \\
\hline$\Sigma$ & 5,00000 & 1,25000 \\
\hline
\end{tabular}

Source: research results based on the field observations.

Seasonality depends on the proximity of the centers of mountain tourism on Zlatar and Zlatibor mountains. Seasonality is less evident on Zlatibor mountain, where there are both summer and winter seasons, while Zlatar Mountain has a more active winter season, 
but when rural tourism is concerned the summer season dominates.

Table 6. Comparison of alternatives in relation to $\mathrm{K} 3$ criterion - accessibility and infrastructure

\begin{tabular}{|c|c|c|}
\hline & $\mathbf{A 1}$ & $\mathbf{A 2}$ \\
\hline $\mathbf{A 1}$ & 1,00000 & 0,20000 \\
\hline $\mathbf{A 2}$ & 5,00000 & 1,00000 \\
\hline$\sum$ & 6,00000 & 1,20000 \\
\hline
\end{tabular}

Source: research results based on the statistical yearbook Municipalities and Regions in the Republic of Serbia, 2013.

Road infrastructure in Serbia is not in the best condition, although it occupies an important place in the development of rural tourism (Vujović et al., 2012). Accessibility and infrastructure, perceived in terms of access and movement possibilities in a particular area, have been analyzed using the statistical data on the length of roads in Nova Varoš and Čajetina municipalities. The total length of roads in Nova Varoš $(543.6 \mathrm{~km})$ and Čajetina $(534 \mathrm{~km})$ is approximate, but there is a difference in the length of municipal roads with modern roadways, with Cajetina showing advantage ( $275 \mathrm{~km}$ of municipal roads with modern roadways) compared to Nova Varoš (107 km of municipal roads with modern roadways). A considerable length of municipal roads in Nova Varoš does not have an asphalt surface $(334 \mathrm{~km})$, which shows that transportation infrastructure is at a low level (Municipalities and Regions in the Republic of Serbia, 2013).

Table 7. Comparison of alternatives in relation to $\mathrm{K} 4$ criterion - proximity of the marketplace

\begin{tabular}{|c|c|c|}
\hline & A1 & A2 \\
\hline $\mathbf{A 1}$ & 1,00000 & 0,33333 \\
\hline $\mathbf{A 2}$ & 3,00000 & 1,00000 \\
\hline$\Sigma$ & 4,00000 & 1,33333 \\
\hline
\end{tabular}

Source: research results based on the field observations.

The position of Zlatibor villages in relation to the emitting centers of tourism is more favorable than the position of villages on Zlatar. As the distance between Zlatar and Zlatibor is not far, it is the experience or judgment that slightly favors the villages on Zlatibor taking into consideration those settlements through which major roads pass show advantage.

Table 8. Comparison of alternatives in relation to K5 criterion - unemployment

\begin{tabular}{|c|c|c|}
\hline & A1 & A2 \\
\hline $\mathbf{A 1}$ & 1,00000 & 5,00000 \\
\hline $\mathbf{A 2}$ & 0,20000 & 1,00000 \\
\hline$\Sigma$ & 1,20000 & 6,00000 \\
\hline
\end{tabular}

Source: research results based on the statistical yearbook Municipalities and Regions in the Republic of Serbia, 2013. 
In Serbia, during the transition period a large number of workers became redundant in privatized firms and those that were liquidated, and the economic crisis influenced further the (un)employment opportunities of the rural population in non-agricultural activities and in the cities. Households in rural areas have started using the available natural, residential, and agricultural resources in order to perform diversification of activities and engage in rural tourism as an additional activity (Ševarlić, Petrović, 2011).

Unemployment data are recorded at the municipal level in the publication Municipalities and Regions in the Republic of Serbia and are not comparable with the international methodology. Therefore, the comparison of alternatives with respect to unemployment as a criterion is generalized and includes the municipalities of Nova Varoš and Čajetina, where the analyzed villages are situated. Statistical data show that the percentage of the unemployed in total active population in Nova Varoš is $30.6 \%$, whereas in the municipality of Čajetina it is $13.5 \%$ (Municipalities and Regions in the Republic of Serbia, 2013). Taking into account the fact that a high rate of unemployment should be given priority in the development of rural tourism, this priority has been given to villages on Zlatar Mountain.

Table 9. Comparison of alternatives in relation to $\mathrm{K} 6$ criterion - accommodation facilities

\begin{tabular}{|c|c|c|}
\hline & A1 & A2 \\
\hline $\mathbf{A 1}$ & 1,00000 & 0,33333 \\
\hline $\mathbf{A 2}$ & 3,00000 & 1,00000 \\
\hline$\Sigma$ & 4,00000 & 1,33333 \\
\hline
\end{tabular}

Source: research results based on information from the websites of local tourism organizations - www.zlatibor.org.rs/k/seoski-turizam, www.zlatar.org.rs/seoski.htm

Accommodation facilities are compared on the basis of local tourism organization data. About 390 beds have been recorded in Zlatibor village, and in the villages on Zlatar Mountain about 350. Taking into account the categorization of accommodation, not just the number, villages on Zlatibor show advantage. In rural areas, housing can be analyzed in the context of the type, location (position and accessibility), quality of services and activities offered to guests by hosts (Albaladejo Pina, Delfa Diaz, 2005). If it is taken into consideration that the forms of rural tourism by length of stay are divided to the excursion and residence stay (Todorović, Štetić, 2009), it can be concluded that in the villages of Zlatar and Zlatibor excursion tourism is dominant. Natural and anthropogenic tourist motives of villages are additions to tourism offer in the mountain resorts of Zlatar and Zlatibor.

Table 10. Comparison of alternatives in relation to $\mathrm{K} 7$ criterion - experience in rural tourism

\begin{tabular}{|c|c|c|}
\hline & $\mathbf{A 1}$ & $\mathbf{A 2}$ \\
\hline $\mathbf{A 1}$ & 1,00000 & 0,33333 \\
\hline $\mathbf{A 2}$ & 3,00000 & 1,00000 \\
\hline$\sum$ & 4,00000 & 1,33333 \\
\hline
\end{tabular}

Source: research results, field observations. 
Although mountain tourism on Zlatibor has a long tradition, rural tourism on this mountain has not developed simultaneously with this dominant form of tourism. Rural tourism on Zlatar Mountain has been developing in recent years, since the accommodation facilities of mountain tourism have been restructured and privatized.

Values in rows A1 and A2 have been calculated on the basis on the values in Tables 4 to 10. When it comes to the $\mathrm{K} 1$ criterion, having compared $\mathrm{A} 1$ and $\mathrm{A} 2$, values have been summarized in each column. Each number in the table has been divided by the sum value in that column. The values of the rows have been summed up and the median value has been determined for each row $(\Sigma=\mathrm{W} / 2)$ in relation to the $\mathrm{K} 1$ criterion. Values of the alternatives have been obtained in the same way when other criteria are considered.

Table 11. Overview of the values of criteria and alternatives in relation to the given criterion

\begin{tabular}{|c|c|c|c|c|c|c|c|}
\hline & K1 & K2 & K3 & K4 & K5 & K6 & K7 \\
\cline { 2 - 8 } & 0,35040 & 0,03180 & 0,23747 & 0,04616 & 0,10556 & 0,15897 & 0,06965 \\
\hline A1 & 0,25000 & 0,20000 & 0,16667 & 0,25000 & 0,83333 & 0,25000 & 0,25000 \\
\hline $\mathbf{A 2}$ & 0,75000 & 0,80000 & 0,83333 & 0,75000 & 0,16667 & 0,75000 & 0,75000 \\
\hline
\end{tabular}

Source: research results calculated on the basis of the results in the previous tables.

The value of a criterion function for the given criterion is multiplied by the weight of the criterion: $\mathrm{A} 1=\mathrm{A} 1 * \mathrm{~K} 1+\mathrm{A} 1 * \mathrm{~K} 2+\mathrm{A} 1 * \mathrm{~K} 3+\mathrm{A} 1 * \mathrm{~K} 4+\mathrm{A} 1 * \mathrm{~K} 5+\mathrm{A} 1 * \mathrm{~K} 6+\mathrm{A} 1 * \mathrm{~K} 7$

Calculation for A2 is performed in the same way. Thus, the final ranking of alternatives A1 - 0.2902, A2 - 0.7098 is obtained. By analyzing alternatives in relation to criteria, it can be concluded that priority is given to villages on Zlatibor, but also that they demonstrate certain weak dominance. The only criterion in which the priority is given to villages on Zlatar is the unemployment because in this area it is higher than in Zlatibor villages.

From the perspective of rural tourism, attention should be paid to the support of public institutions engaged in the establishment of private enterprises, small family businesses in order to empower rural areas economically and promote tourism related activities (Fleischer, Felsenstein, 2000), paying special emphasis on the sustainability of rural tourism (Sanagustin Fons et al., 2011).

Natural characteristics of a rural area are not a sufficient condition so that it may become a tourist destination. It is therefore necessary to develop receptive and communication capacities and provides high quality of additional tourist spending offers. The competitiveness of rural tourism destinations will depend on these elements and their development. This is the imperative for tourism development today that many rural areas that tend to be involved in tourism do not possess (Vuković et al., 2010). The same can be concluded when it comes to villages on Zlatar and Zlatibor Mountains.

Development of rural tourism should take advantage of the challenges of agriculture that are reflected in the exchange of goods in the sectors of tourism and agriculture (food and beverages), intangible impact on rural tourism (preserved natural environment), 
employment opportunities and improvement of cultural tourism of a local community (Milenković, Utvić, 2013).

Insufficient development of villages and agriculture slows down the overall development, which should condition a more complex model of development policy towards the countryside and rural society. In this context a multidisciplinary-based model of integral rural tourism development could be applied. Investment in these areas is crucial to their attractiveness, encouragement of sustainable growth and employment (Štetić et al., 2012). Integrated rural tourism provides greater likelihood of coordination and consistent institutional policy for rural and regional development while simultaneously encouraging partnerships between local stakeholders, ones that can provide broader development benefits arising from mergers and synergies (Štetić et al., 2012*).

\section{Conclusion}

In the future development of tourism in rural settlements on Zlatibor and Zlatar activities should be directed towards greater utilization of accommodation facilities, improvement of infrastructure, promotion and propaganda, education of the local population on the provision of tourism services, and financial stimulation. By connecting clusters in tourism with clusters in agriculture, a tourism complementary field, beneficial effects could be achieved in rural settlements on Zlatibor and Zlatar. Cooperation of agricultural producers is evident in villages on these mountains when animal breeding on Zlatibor and production of buckwheat on Zlatar is concerned.

Losing position in relation to competition is manifested as one of the risks in rural tourism industry. Villages on Zlatibor and Zlatar mountains, although similar in certain characteristics, should present at the tourism marketplace the attributes that make them different from the others, while acknowledging and accepting the vision of rural tourism importance, and appreciating the good practice.

\section{References}

1. Albaladejo Pina, I., Diaz Delfa, M. (2005): Rural tourism demand by type of accommodation, Tourism Management, Vol. 26, no. 6, pp. 951-959, Elsevier (printed in Great Britain), available at: www.sciencedirect.com/science/article/ pii/S0261517704001384

2. Fleischer, A., Felsenstein, D. (2000): Suport for rural tourism. Does it Make a Difference?, Annals of Tourism Research, Vol. 27, No. 4, pp. 1007-1024, Elsevier (printed in Great Britain), available at: www.researchgate.net/profile/Daniel Felsenstein/publication/223510803 Support for rural tourism Does it make a difference/fileort/9c96052124b3d449b7.pdf

3. Master plan održivog ruralnog turizma Srbije, UN (Svetska turistička organizacija), Srbija, 2011, available at: www.futurehospitalityleaders.files.wordpress.com/2012/11/ master-plan-odrzivog-razvoja-ruralnog-turizma-u-srbiji.pdf

4. Milenković, S., Utvić, S. (2013): The challenges of rural areas in Serbia promising tourist activities, Economics of Agriculture, Vol. 60, No. 1, pp. 65-76, IAE, Belgrade. 
5. Republički zavod za statistiku (2013): Opštine i regioni u Republici Srbiji 2013. Stanovništvo prema ekonomskoj aktivnosti, Dužina puteva, Beograd, Srbija, available at: www.pod2.stat.gov.rs Objavljene PublikacijeOpsOPS2013.pdf

6. Saaty, T. L. (1990): How to make a decision: The Analytic Hierarchy Process, European Journal of Operational Research, Vol. 48, no. 1, pp. 9-26, Elsevier (North Holland), available at: www.ac.els-cdn.com/037722179090057I/1-s2.0037722179090057I-main.pdf? tid=8f43f0ac-ff96-11e3-b60a-00000aab0f6b\&acdnat $=1404050966$ 61aed2844855472e6a06b4968b813a17

7. Sanagustin Fons, V., Mosene Fierro, J., Gomez y Patino, M. (2011): Rural tourism: A sustainable alternative, Applied Energy, Vol. 88, pp. 551-557, Elsevier (printed in Great Britain), available at: www.arquivo.rosana.unesp.br/docentes/patriciaramiro/ LEAR/Turismo\%20rural\%20uma\%20alternativa\%20sustentável.pdf

8. Ševarlić, M., Petrović, Z. (2011): Razvoj seoskog turizma u opštini Gornji Milanovac - ugledni primer za sela Srbije, Ekonomika poljoprivrede, Vol. 58, No. 3, pp. 457-473, IAE, Belgrade.

9. Štetić, S. (2007): Turistička geografija Srbije, Izdavač Autor, Beograd, Srbija.

10. Štetić, S., Pavlović, S., Stanić, S. (2012): Integrisani ruralni razvoj turizma - studije slučaja zapadna Irska i Avinjon i Istočna Srbija, Hotellink, časopis za teoriju i praksu hotelijerstva, Vol. 13, br. 19-20, pp. 56-65, Visoka hotelijersta škola, Beograd, Srbija.

11. Štetić S., Pavlović S., Stanić S. (2012*): Integrisani ruralni turizam kao mogućnost razvoja sela, Zbornik radova sa konferencije - Prvi stručni skup o ruralnom turizmu i održivom razvoju, Kragujevac, Srbija, pp. 142-149.

12. Štetić, S., Šimičević, D., Čurčić, N. (2013): Specifični oblici turizma, Izdavač Autor, Beograd, Srbija.

13. Todorović, M., Štetić, S. (2009): Ruralni turizam, Univerzitet u Beogradu - Geografski fakultet, Beograd, Srbija.

14. Turistička organizacija Zlatibor (2014): Informacije o seoskom turizmu na Zlatiboru, available at: www.zlatibor.org.rs/k/seoski-turizam

15. Turističko-sportski centar Zlatar (2014): Informacije o seoskom turizmu, dostupno na: www.zlatar.org.rs/seoski.htm

16. Vujović, S., Cvijanović, D., Štetić, S. (2012): Destinacijski koncept razvoja turizma, Institut za ekonomiku poljoprivrede, Beograd, Srbija.

17.Vuković, P., Arsić, S., Cvijanović, D. (2010): Konkurentnost ruralnih turističkih destinacija, Ekonomika poljoprivrede, Vol. 57, No. 1, pp. 47-60, IEP, Beograd. 


\title{
KONKURENTNOST TURISTIČKIH DESTINACIJA U KLASTERU RURALNOG TURIZMA ZLATAR, ZLATIBOR
}

\author{
Sanja Pavlovićc ${ }^{3}$ Gordana Čavlin ${ }^{4}$
}

\begin{abstract}
Rezime
U savremenom razvoju turizma klasterska analiza dobija sve veći značaj. Uglavnom se radi o prostorima koji imaju slične turističke vrednosti. U ovom radu je prikazana konkurentnost turističkih destinacija u klasteru ruralnog turizma Zlatar, Zlatibor, definisanom Master planom održivog razvoja ruralnog turizma u Srbiji. AHP metodom (analitički hijerarhijski proces) najpre su upoređeni kriterijumi u parovima, a zatim i alternative (seoska naselja Zlatara i Zlatibora). Sedam kriterijuma korišćenih u ovom radu su: faktori $i$ atraktori, pristupačnost i infrastruktura, smeštajni kapaciteti, nezaposlenost, iskustvo u ruralnom turizmu, blizina tržišta, sezonska uslovljenost. AHP metodom su utvrđene relacije između uticajnih faktora i određena dominantnost jednog faktora u odnosu na drugi. Konstatovana je relativno slaba dominantnost seoskih naselja Zlatibora, po svim kriterijumima, osim kada je u pitanju nezaposlenost, gde dominiraju seoska naselja na Zlataru.
\end{abstract}

Ključne reči: ruralni turizam, konkurentnost, klaster, Zlatar, Zlatibor.

3 Sanja Pavlović, Ph.D., docent, Univerzitet u Beogradu, Geografski fakultet, Studentski trg 3/III, 11000 Beograd, Srbija, Telefon:+381 6425884 68, E-mail: spavlovic20@gmail.com

4 Gordana Čavlin, mr. sci. oecc., Pokrajinski sekretarijat za zdravstvo i socijalna pitanja - Novi Sad, Odeljenje Subotica, Telefon: + 3816288487 36, E-mail: goca.cavlin@gmail.com 